University of Nebraska - Lincoln

DigitalCommons@University of Nebraska - Lincoln

2006

Critical Analysis of Coprolite Evidence of Medicinal Plant Use, Piauí, Brazil

Sérgio Augusto de Miranda Chaves

FIOCRUZ, smiranda@ensp.fiocruz.br

Karl J. Reinhard

University of Nebraska at Lincoln, kreinhard1@mac.com

Follow this and additional works at: https://digitalcommons.unl.edu/anthropologyfacpub

Part of the Anthropology Commons

Miranda Chaves, Sérgio Augusto de and Reinhard, Karl J., "Critical Analysis of Coprolite Evidence of Medicinal Plant Use, Piauí, Brazil" (2006). Anthropology Faculty Publications. 25.

https://digitalcommons.unl.edu/anthropologyfacpub/25

This Article is brought to you for free and open access by the Anthropology, Department of at DigitalCommons@University of Nebraska - Lincoln. It has been accepted for inclusion in Anthropology Faculty Publications by an authorized administrator of DigitalCommons@University of Nebraska - Lincoln. 
Published in Palaeogeography, Palaeoclimatology, Palaeoecology 237 (2006) 110 -118.

Copyright 2006, Elsevier. www.elsevier.com/locate/palaeo. doi:10.1016/j.palaeo.2005.11.031.

Used by permission.

\title{
Critical Analysis of Coprolite Evidence of Medicinal Plant Use, Piauí, Brazil
}

\author{
Sérgio Augusto de Miranda Chaves ${ }^{\mathrm{a},{ }^{,}}$, Karl J. Reinhard ${ }^{\mathrm{b}}$

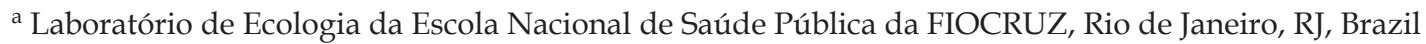 \\ (smiranda@ensp.fiocruz.br) \\ b School of Natural Resources, University of Nebraska-Lincoln, Lincoln, NE, United States
}

Received November 19, 2003; accepted November 8, 2005.

\begin{abstract}
Human coprolites, dating from 8,500 to 7,000 years BP, were collected from the rock-shelter of Boqueirão da Pedra Furada, in Piauí, Brazil. These dates fall within the "Serra Talhada" cultural traditions I and II of the Tradição Nordeste, a paleohuman culture of northeastern Brazil. Archaeoparasitological analysis of the coprolites revealed whipworm eggs and hookworm eggs. Analysis of Tradição Nordeste skeletons and hair shows a variety of diseases including dental problems, osteoarthritis, and head louse infestation. Palynological analysis of the coprolites revealed 12 genera that were potentially medicinal. The pollen data were critically analyzed to assess the potentiality that the pollen represented medicinal use. Strong cases could be made that three of the genera, Anacardium, Borreria, and Terminalia, were actually used for medicinal purposes, probably to treat symptoms caused by the intestinal parasites.
\end{abstract}

Keywords: Palynology; Paleopharmacology; Paleopathology; Archaeoparasitology; Ethnobotany

\section{Introduction}

The archaeology of the arid Sertão of northeastern Brazil provides a rich source of information about the first American cultures. The Sertão includes the caatinga which is a large, semiarid region that includes portions of the Brazilian states of Piauí, Ceará, Rio Grande do Norte, Algoas, Paraiba, Pernambuco, Sergipe, Bahia, and Minas Gerais. In the Sertão, the oldest paleohuman culture, called the Tradição Nordeste (Northeastern Tradition) has been documented by burials, rock art, and associated artifacts from several well dated sites (Guidon et al., 1994; Martin, 1997;
Chaves, 2000; Lessa and Guidón, 2002).

Analysis of coprolites, skeletons, and hair provide evidence of pathology that would have required knowledge of traditional medicines for the Tradição Nordeste. Araújo et al. (2000) found louse eggs on isolated hair shafts dating over 10,000 years ago. Repellents or delousing remedies would have reduced the annoyance of these parasites. Reinhard et al. (2001) point out that the oldest hookworm infections were diagnosed from Tradição Nordeste coprolites. Whipworms also parasitized this culture (Gonçalves et al., 2003). Anthelminthics and treatments for the symptoms of worm infection would have been needed. 
Lessa and Guidón (2002) found evidence of degenerative disease and oral pathology that would have required analgesics.

Paleopharmacology is the study of medicinal remains from archaeological sites (Reinhard et al., 1991; Reinhard, 2000; Chaves and Reinhard, 2003). The theoretical foundation for the field is Ortiz's (1975) study of Aztec medicinal plants identified in an historical codex. Coprolite analysis has obvious implications for the field and can extend our knowledge of medicinal plants far back in time. Fry (1977) found medicinal bark in coprolites from the Archaic period of the Great Basin. As reviewed by Riley (1993), numerous researchers following Reinhard et al. (1985) established the use of seeds to identify prehistoric use of vermifuges. With regard to the general picture of Chenopodium (worm seed) use, Reinhard (2000:445) wrote, "One of the significant aspects of these Chenopodium studies is the depiction of the development of pharmaceuticals in prehistory. Species of Chenopodium were used by ancient hunter-gatherers and agriculturalists primarily as a food source. As knowledge of various species of Chenopodium progressed, there came the recognition that certain species had a pharmacological value."

Reinhard et al. (1991) proposed the use of pollen concentration in conjunction with pollen percentages to identify medicinal plant use from coprolite study. They argued that the discovery of Salix (willow), Larrea (creosote), and Ephedra (Mormon tea) in high percentages and concentrations indicated the use of specific treatments. They presented a case that making a tea of foliage or contaminated bark from these plants introduced pollen into the digestive tracts of prehistoric people. One principle established in their work related to the value of pollen concentration in identifying intentional consumption of anemophilous plants (wind pollinated) versus entomophilous (insect pollinated) plants. With entomophilous plants, simple percentage expressions of pollen spectra are usually adequate to identify intentional use. This is not always the case with anemophilous plants since such plants dominate the natural pollen rain. They concluded that pollen concentration data are needed to determine whether anemophilous types were fortuitously incorporated in coprolites or were intentionally consumed with pollen-rich medicines. Thus, with entomophilous taxa, analysis of pollen percentages provides insight into human us of plants. Pollen concentration is often needed for anemophilous taxa.

Beyond the utility of pollen concentration, interpretation questions emerged. Williams-Dean (1978) questioned whether eating willow catkins, as a di- etary source, would mimic the consumption of medicine as interpreted by Reinhard et al. (1991). Reinhard (1993) responded that presence of pollen aggregates should be evident if catkins were eaten. Aggregates are clumps of pollen that never dispersed from their source. Such clumps are eaten with buds, flowers, and even seeds (Bohrer, 1981). In their prior analysis, Reinhard et al. (1991) did not observed aggregates. Another issue raised by Shafer et al. (1989) related to the pollen evidence of multiple medicinal plants. Shafer et al. (1989) found high concentrations of willow and Brassicaceae (mustard family) pollen in coprolites from a burial in New Mexico. The main dietary component was very finely ground maize, probably derived from a maize broth. No mustard family seeds were found in the macroscopic analysis. Some plants in the mustard family are emetics and it seemed possible that two medicines were given to this dying individual. Because the mustard pollen could be identified only to family, this potential could not be further explored. It seems probable that multiple remedies were administered to sick individuals since a single disease can cause several symptoms.

Some of these issues were addressed by Reinhard et al. (2002). These authors conducted a pollen concentration analysis and pollen aggregate analysis of 25 coprolites. By comparing the pollen content of different taxa, background pollen values were assessed. Values that deviated greatly from background values signaled intentional use of plants. Pollen aggregates of dietary and medicinal plants were found. Reinhard et al. (2002) found that willow, Mormon tea, and possibly Yucca (yucca) were used as medicines. However, yucca buds are also a food as well as a medicine.

Much is known about the Brazilian indigenous pharmacopoeia. However, paleopharmacology is in its infancy in Brazil with regard tracing prehistoric medicinal plant use. We are taking this opportunity to present the findings from five coprolites with respect to medicinal plant identification and propose lines of research to expand the field of paleopharmacology in Brazil.

\section{Study region}

The semi-arid Sertão region of Northeast Brazil includes the caatinga (scrub forest) biome. This is a threatened ecological system and less than $50 \%$ of the original caatinga now survives. Furthermore less than $1 \%$ of the caatinga is legally protected in the form of federal conservation reserves. Serra da Capivara National Park, an International Cultural Landmark, is located in the southeastern region of the State of Piauí. 


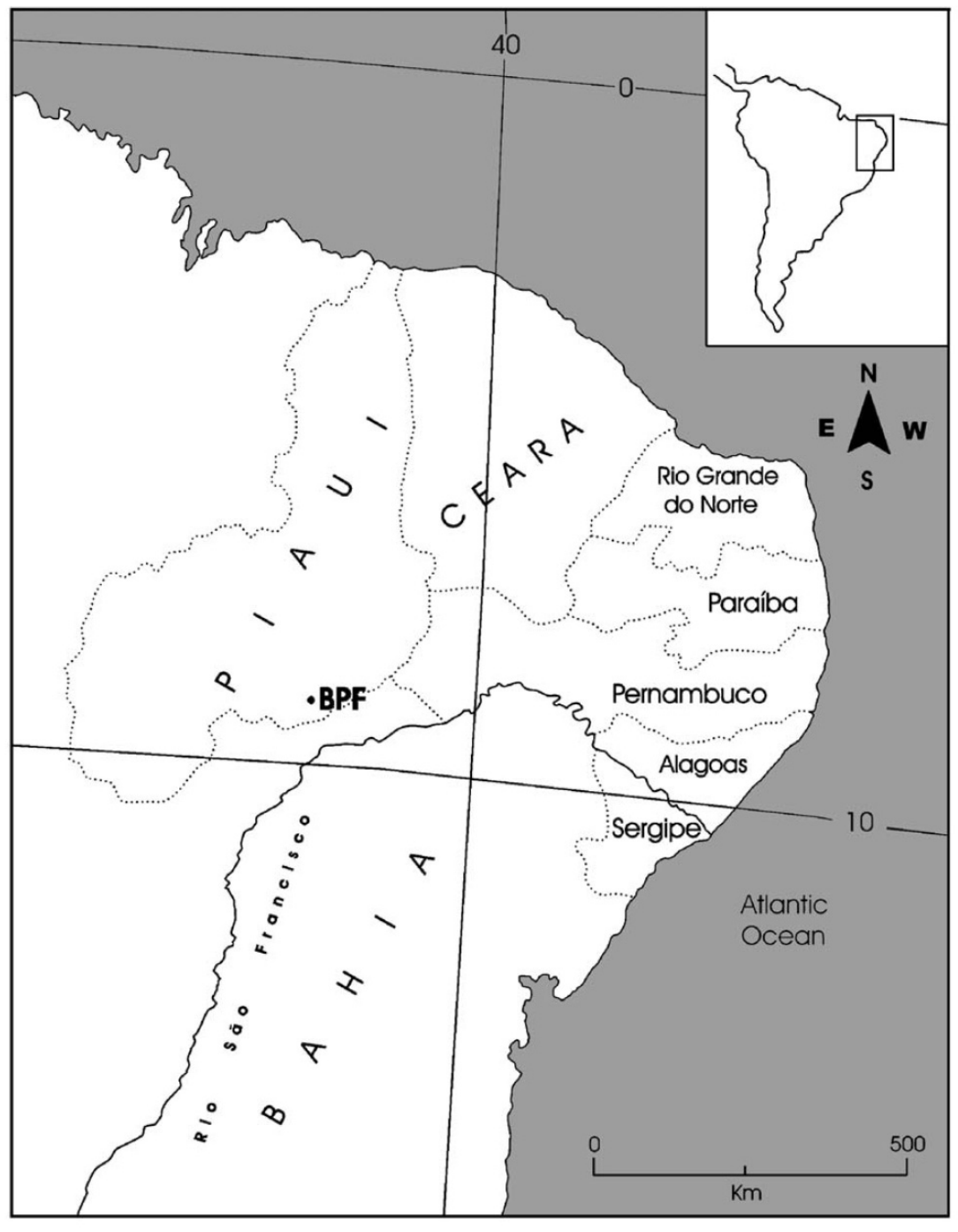

BPF = Boqueirão da Pedra Funda

Fig. 1. Location of study site Boqueirão da Pedra Furada (BPF).

It harbors some 130,000 hectares of caatinga including endemic and endangered plant and animal species from the Brazilian semi-arid ecosystem. The park also has over 700 archeological sites. Multidisciplinary studies have been conducted in the area since 1970. These include ecological, archaeological, parasitological, conservation, botanical, and palynological studies focusing towards economic development of the area without impacting the caatinga. Palynological studies focus on paleoethnobotany and paleoclimate (Chaves, 2000).

Our study is directed towards the coprolites collected in sediments from the rock-shelter of Boqueirão da Pedra Furada (BPF) located in Piauí State, north- east Brazil ( $\left.8^{\circ} 50^{\prime} 10^{\prime \prime} \mathrm{S}-42^{\circ} 33^{\prime} 20^{\prime \prime} \mathrm{W}\right)$ (Figure 1). This site may contain one of the oldest human occupations in the Americas. It is a significant Tradição Nordeste site and has a long, continuous carbon-14 date sequence (Martin, 1997). This rock-shelter presents a 5-meterthick fill whose sequence contains 3 Pleistocene and 3 Holocene human occupational layers. Three levels containing coprolites were found. They are dated as follows: Gif $6162(89 \mathrm{~cm}): 8450$ +/-80 BP, Gif $6161(80$ $\mathrm{cm}): 7750+/-80 \mathrm{BP}$, and Gif $7242(60 \mathrm{~cm}): 7230+/-80$ $\mathrm{BP}$. The dates were obtained using radiocarbon at Gifsur-Yvette Laboratories (France). These levels date to the "Serra Talhada" cultural traditions I and II of the Tradição Nordeste. This is a early period of hunter- 
gatherer adaptation to the region (Martin, 1997).

\section{Methods}

Five coprolites were selected from three different layers to insure that they were defecated by different individuals at different times. The pollen was extracted from the coprolites at the Palynological Unit of the Laboratoire de Préhistoire of the Museum National d'Histoire Naturelle, France. The methods used in this process have been detailed elsewhere (Chaves and Renault-Miskovsky, 1996; Chaves, 2000). The samples were processed in $50 \% \mathrm{HCl}$ and $10 \% \mathrm{KOH}$. The resulting solutions were separated in zinc chloride heavy density solution.

\section{Results}

In total, 15 arboreal taxa and 15 non-arboreal taxa were found. Of interest for this paper, 12 taxa were found from genera that have medicinal species (Tables 1 and 2). These ranged from trace amounts to as much as $35 \%$ of the pollen encountered in a given coprolite. These taxa are the focus for this paper.

\section{Discussion}

The discovery of pollen from plants with medicinal use is not by itself evidence of medicinal application. To make that interpretation, several questions must be asked and answered. Is there evidence of prehistoric pathology that would have required treatment? Does the therapeutic property of the plant match paleo-
Table 2

Scientific name, common Brazilian name, and English translation for the taxa

\begin{tabular}{lll}
\hline Genus & $\begin{array}{l}\text { Common name } \\
\text { Portuguese }\end{array}$ & English meaning \\
\hline Alternathera & - & \\
Anacardium & Caju & Cashew \\
Anandenanthera & Angico & - \\
Bauhinia & Mororo-do-sertão & Mororo of the Sertão \\
Borreria & Cabeça-de-velho & Old man's head \\
Caesalpinia & Pau-ferro & Iron wood \\
Cecropia & Embauba & - \\
Chenopodium- & Mentruz & Derived from mastruço, \\
type & & worm plant \\
Croton & Marmeleiro, velame & Marmeleiro, medicine plant \\
Mansoa & Cipo-de-alho & Garlic weed \\
Sida & Malva-benta & - \\
Terminalia & Maçarico & - \\
\hline
\end{tabular}

pathological medicinal needs? Is it likely that pollen will be carried by the part of the plant that is used ethnographically for medicine? Is it likely that pollen will persist in the application of the medicine? Is the pollination strategy of the plant in question prone to be represented in normal pollen rain? Can pollen be used to make a refined identification of medicinal genera or species? Is the amount of pollen present in the coprolites consistent with medicinal usage? Answering the questions is difficult because there has been no pollen analysis of traditional medicinal preparations. Thus, answers to the questions are based on basic knowledge of pollenation strategies combined with ethnobotanical and paleopathological information.

Is there evidence of prehistoric pathology that would have required treatment? If there is no pathol-

Table 1

Pollen counts and percentage expressions for the five coprolites studied

\begin{tabular}{|c|c|c|c|c|c|c|c|c|c|c|}
\hline \multirow{2}{*}{$\frac{\text { Coprolite }}{\text { Taxon }}$} & \multicolumn{2}{|l|}{1} & \multicolumn{2}{|l|}{2} & \multicolumn{2}{|l|}{3} & \multicolumn{2}{|l|}{4} & \multicolumn{2}{|l|}{5} \\
\hline & \# & $\%$ & \# & $\%$ & \# & $\%$ & \# & $\%$ & \# & $\%$ \\
\hline Alternanthera & 618 & 35.3 & 8 & 0.4 & 73 & 3.9 & 149 & 10.7 & 32 & 2.7 \\
\hline Anacardium & 7 & 0.4 & 6 & 0.3 & 0 & 0 & 171 & 12.2 & 30 & 2.5 \\
\hline Anadenanthera & 0 & 0 & 0 & 0 & 0 & 0 & 5 & $\mathrm{t}$ & 0 & 0 \\
\hline Bauhinia & 28 & 1.6 & 0 & 0 & 55 & 3 & 0 & 0 & 6 & 0.5 \\
\hline Borreria & 460 & 26.3 & 519 & 23 & 0 & 0 & 311 & 22.2 & 323 & 26.9 \\
\hline Caesalpinia & 0 & 0 & 0 & 0 & 6 & 0.3 & 0 & 0 & 0 & 0 \\
\hline Cecropia & 28 & 1.6 & 0 & 0 & 6 & $\mathrm{t}$ & 0 & 0 & 0 & 0 \\
\hline Chenopodium-type & 35 & 2 & 81 & 3.6 & 0 & 0 & 39 & 2.8 & 221 & 18.4 \\
\hline Croton & 8 & 0.5 & 31 & 1.4 & 24 & 1.3 & 9 & 0.6 & 92 & 7.7 \\
\hline Mansoa & 6 & 0.3 & 0 & 0 & 9 & 0.5 & 0 & 0 & 0 & 0 \\
\hline Sida & 84 & 4.8 & 309 & 13.7 & 119 & 6.4 & 298 & 21.3 & 0 & 0 \\
\hline Terminalia & 151 & 8.6 & 139 & 6.2 & 163 & 8.8 & 37 & 2.6 & 135 & 11.3 \\
\hline
\end{tabular}

Only the potential medicinal taxa are considered here. Percentages exceeding $4 \%$ are in bold. 
ogy, then a medicinal interpretation of pollen is less valid. With regard to the Tradição Nordeste in general and Serra da Capivara National Park in specific, there is paleopathological evidence of medicinal plant need. Dental abscesses, osteoarthritis, and fractures were health problems (Lessa and Guidón, 2002). Whipworm causes blood loss, trauma to the intestinal epithelium and underlying submucosa with chronic hemorrhage. Anemia possibly resulted. Today, secondary bacterial infections can lead to colitis, and proctitis. Rectal prolapse also occurs in whipworm infected children. Potentially these symptoms threatened some prehistoric people infected by whipworms. Insomnia, nervousness, loss of appetite, vomiting, urticaria, prolonged diarrhea, constipation, and flatulence are and were further symptoms of whipworm infection. Hookworm causes more severe disease. There is itching and a rash at the place where the larvae penetrate the skin. Once the worms become established in the intestine, they can cause anemia, abdominal pain, diarrhea, loss of appetite, and loss of weight. These problems were probably present in some prehistoric people hosting hookworms. Head lice cause itching and rash. Based on this limited data, a variety of medicinal plants would have been useful to the Tradição Nordeste paleohumans in Serra da Capivara National Park.

Does the therapeutic property of the plant match paleopathological medicinal needs? If the prehistoric symptoms could have been treated by the plants, than a medicinal interpretation of pollen is more valid. Emperaire (1983) assembled the medicinal folk ethnobotany for the area of Serra da Capivara National Park. The Checklist das Plantas do Nordeste (Versão 11.2) data base by Gamarra-Rojas et al. (2002) lists caatinga medicinal plants, the maladies treated by the plants, preparation methods, and other details. Some of the medicinal plant genera Emperaire (1983) and Gamarra-Rojas et al. (2002) list are represented by pollen in the coprolites. The therapeutic value of the plants are relevant to paleopathological health problems (Table 3). Two genera contain anthelminthic species (Chenopodium-type and Bauhinia). Several others are useful in treating the symptoms of parasitic worms (Borreria, Terminalia, Alternathera, Anacardium, and Caesalpinia). Others are analgesics (Croton, Cecropia) and one is good for treating sore gums and tooth-aches (Anandenanthera). Superficial wounds are problems for all populations and Sida is used for first aid treatment of such problems. Mansoa, is used for sore throats and diabetes. It is possible that this plant was needed for sore throats. It is unlikely that diabetes would have been a health problem in prehistory. Of the twelve potential medicinal plant genera found in the three co-
Table 3

Basic pharmacological information for the taxa from Emperaire (1983) and Gamarra-Rojas et al. (2002)

\begin{tabular}{|c|c|c|}
\hline Genus & Part used & Remedy for \\
\hline Alternathera & Leaves & Inflammation, cough, dysentery \\
\hline Anacardium & Leaves, bark & Dysentery, bleeding \\
\hline Anandenanthera & Bark & $\begin{array}{l}\text { Tuberculosis, respiratory infections, } \\
\text { sore gums, tooth-aches }\end{array}$ \\
\hline Anandenanthera & $\begin{array}{l}\text { Syrup made } \\
\text { of resin }\end{array}$ & Expectorant \\
\hline Bauhinia & $\begin{array}{l}\text { Infusion of } \\
\text { bark }\end{array}$ & Helminth infection, eye irritation \\
\hline Borreria & $\begin{array}{l}\text { Foliage } \\
\text { infusion }\end{array}$ & Digestive problems \\
\hline Caesalpinia & $\begin{array}{l}\text { Bark } \\
\text { infusion }\end{array}$ & 'Healing infusion' \\
\hline Caesalpinia & $\begin{array}{l}\text { Flowers, leaf } \\
\text { infusion }\end{array}$ & Dysentery \\
\hline Cecropia. & Leaves & Pain \\
\hline $\begin{array}{l}\text { Chenopodium- } \\
\text { type }\end{array}$ & Leaves & Helminth infection, \\
\hline Croton & Leaves & $\begin{array}{l}\text { Rhumatism, head-ache, influenza, } \\
\text { bronchitis }\end{array}$ \\
\hline Mansoa & Leaves & Sore throat, diabetes \\
\hline Sida & Poltice & Wounds \\
\hline Terminalia & $\begin{array}{l}\text { Foliage } \\
\text { infusion }\end{array}$ & Dysentery \\
\hline
\end{tabular}

prolites, all were needed by the prehistoric people in the region. For the most part, the therapeutic properties of the plants match paleopathological medicinal needs. Is it likely that pollen will be carried by the part of the plant that is used ethnographically for medicine? The part of the plant used for medicine affects the potential of finding pollen in coprolites from medicinal preparations. Obviously, medicines made from buds or flowers have a high probability of containing pollen. Medicines made foliage including buds or flowers also have a good potential to contain pollen. If bark or foliage excluding flowers or buds is the source for the medicine, then there may be some contamination with anemophilous pollen taxa. Finally, tubers, corms and other underground organs will not contain pollen and medicines made from such organs will be pollen-free.

Emperaire (1983) found that infusions of foliage were made from Alternathera, Anacardium, Borreria, Sida, Terminalia, Caesalpinia, Cecropia, Croton, Mansoa, and Chenopodium-type. Infusions of flowers were made from Caesalpinia. Therefore, it is possible that pollen would have been incorporated in medicines made from these plants. Medicinal preparations were made from Anandenanthera bark and resin. It is less likely that pollen would have been incorporated in medicine made from this entomophilous plant. 
Bauhinia-derived medicines are also made from bark. Therefore it is unlikely that medicine derived from this entomophilous genus carried pollen. Thus, ten of the twelve genera possibly produced pollen carrying medicine.

Is it likely that pollen will persist in the application of the medicine? All medicines derived from the observed genera, except that derived from Sida, were taken internally. Sida is applied externally to wounds. Therefore, it is very unlikely that pollen from a Sidaderived poultice would enter the digestive system. However, pollen from the other plants, especially those made from foliage and flowers could have been ingested.

Is the pollination strategy of the plant in question prone to be represented in normal pollen rain? If the pollination strategy of a medicinal plant is anemophily, then the discovery of pollen from the plant could be explained by contamination of food or drink with by ambient pollen rain (Hevly, 1981; Bryant and Holloway, 1983; Sobolik, 1988; Reinhard et al., 1991; Reinhard and Bryant, 1992). In the case of medicinal genera discussed here, all but Chenopodium-type and Anacardium are entomophilous or zoophilous. Therefore, it is difficult to explain the presence of ten of twelve genera on the basis of contamination.

Can pollen be used to make a refined identification of medicinal genera or species? This is a key question and relates to two issues: Do all species in the genus have medicinal value? If this is true, then identification to the genus level is sufficient to make a medicinal interpretation. Are there many genera and species in a family with similar pollen? If this is true, and if the list of similar types includes medicinal, dietary, and useless species, then making a medicinal interpretation is unwise. Among the genera presented here, only Chenopodium-type shares a morphology with non-medicinal taxa in the Chenopodiaceae and Amaranthaceae. Therefore, it is not wise to infer medicinal use of Chenopodium-type without more intensive, critical analysis. Of the other genera, much more information about medicinal plant use must be compiled. A review of the Checklist das Plantas do Nordeste (Versão 11.2) data base (Gamarra-Rojas et al., 2002), shows that relatively little is known about the medicinal value of caatinga plants. The number of medicinal species for each genus found in the coprolites is presented in Table 4.

For some genera such as Anandenanthera, Alternathera, Anacardium, Borreria, Caesalpinia, and Cecropia, the majority of species have recorded medicinal value and raises the likelihood that pollen of these genera in coprolites could be due to medicinal use. However, for other genera such as Croton which has only one of 27 species listed as medicinal, it is less likely that pol-
Table 4

Pollination strategy and number of medicinal species recorded over all species in the caatinga checklist

\begin{tabular}{|c|c|c|c|}
\hline Genus & Pollination & $\begin{array}{l}\# \\
\text { medicinal } \\
\text { species/\# } \\
\text { all species }\end{array}$ & $\begin{array}{l}\text { Likelihood of pollen } \\
\text { in medicinal } \\
\text { preparation }\end{array}$ \\
\hline Alternathera & Anemophilous & $1 / 1$ & $\begin{array}{l}\text { Problematic - wind } \\
\text { pollinated }\end{array}$ \\
\hline Anacardium & Entomophilous & $1 / 1$ & $\begin{array}{l}\text { Poor if bark is used, } \\
\text { good if leaves are } \\
\text { used }\end{array}$ \\
\hline Anandenanthera & Entomophilous & $1 / 2$ & $\begin{array}{l}\text { Poor if bark is used, } \\
\text { fair if resin is used }\end{array}$ \\
\hline Bauhinia & Entomophilous & $1 / 4$ & Poor \\
\hline Borreria & Entomophilous & $(1) / 1$ & Good \\
\hline Caesalpinia & Entomophilous & $3 / 5$ & $\begin{array}{l}\text { Good if leaves are } \\
\text { used, excellent in } \\
\text { flowers used }\end{array}$ \\
\hline Cecropia & $\begin{array}{l}\text { Entomophilous, } \\
\text { zoophilous }\end{array}$ & $(1) /(1)$ & Good \\
\hline $\begin{array}{l}\text { Chenopodium- } \\
\text { type }\end{array}$ & Anemophilous & $(1) /(1)$ & $\begin{array}{l}\text { Problematic-pollen } \\
\text { cannot be identified } \\
\text { to medicinal species } \\
\text { and wind pollinated }\end{array}$ \\
\hline Croton & Entomophilous & $(1) / 27$ & Good \\
\hline Mansoa & Entomophilous & $(0) / 1$ & Good \\
\hline Sida & Entomophilous & $2 / 6$ & $\begin{array}{l}\text { Poor-external } \\
\text { application }\end{array}$ \\
\hline Terminalia & Entomophilous & $(1) / 5$ & Good \\
\hline
\end{tabular}

Numbers in parenthesis are from Emperaire's (1983) summary of Piaui folk medicine and numbers not in parentheses are from the caatinga checklist (Gamarra-Rojas et al., 2002). For example ' $3 / 5$ ' indicates that Gamarra-Rojas et al. (2002) recorded three medicinal species from five total species of the indicated genus known from the caatinga. '(3)/5' means that the medicinal taxa were recorded by Emperaire (1983) and the total number of taxa by Gamarra-Rojas et al. (2002). '(3)/(5)' means all data come from Emperaire (1983). Gamarra-Rojas et al. (2002) did not cite Emperaire's (1983) in the plant checklist literature. The final column presents an estimate of the probability that pollen from the taxa would be incorporated in medicinal preparations.

len would be associated with medicinal use.

Is the amount of pollen present in the coprolites consistent with medicinal use? Reinhard et al. (1991) addressed this issue. With entomophilous taxa, assessing simple percentages is often effective in identifying intentional use of a plant taxon. Very low percentages could be due to fortuitous ingestion of ambient pollen. Because pollen from any given entomophilous taxon rarely makes up more than $4 \%$ of ambient pollen, percentages exceeding $4 \%$ could signal intentional use of that taxon (Bryant and Holloway, 1983). All of the potential medicinal taxa except for Alternanthera and Chenopodium-type are entomophilous. The percent- 
ages for the taxa are presented in Table 1. For Anacardium, Borreria, Croton, Sida, and Terminalia the pollen percentages exceed $4.0 \%$ for at least one coprolite. Therefore, there is the potential that the pollen data signal the intentional use of these plants. Reinhard et al. (1991) stressed the importance of using pollen concentration for interpreting intentional use of anemophilous taxa. In this case, Chenopodium-type and $\mathrm{Al}$ ternanthera are wind pollinated and without pollen concentration analysis, interpreting intentional use is difficult. The $18.4 \%$ value for Chenopodium-type and the $35.3 \%$ value for Alternanthera could be due to the intentional use of these plants, but also might have resulted from contamination of food or drink with ambient pollen. It is impossible to say.

Table 5 summarizes the data for all of the coprolites. All of the taxa have medicinal properties useful to prehistoric hunter-gatherers of the Tradição Nordeste. Because the medicinal preparations of bark and resin will probably carry trace amounts of pollen from entomophilous plants, it is unlikely that Borreria and Anadenanthera would be represented by pollen in medicines. If prehistoric people used a poultice made of Sida like ethnographic peoples, then the high percentages of Sida in four coprolites must represent an intentional, but non-medicinal use. Medicinal interpretation of Croton is problematic because there are many species in the area that do not have recorded medicinal value. Wind pollination increases the potential that a taxon would be fortuitously ingested. Because Chenopodium-type and Alternanthera are anemophilous, interpreting the pollen evidence of these taxa is problematic. Finally, of the remaining taxa, only
Anacardium, Borreria, and Terminalia have high pollen percentages in one or more coprolites. Therefore, we must conclude that of the twelve potential medicinal genera that we found, only Anacardium, Borreria, and Terminalia remain as strong candidates for actual prehistoric medicinal use. It is noteworthy that all three of these candidates are used to treat maladies of digestive tract and two are dysentery treatments. This correlates well to the archaeoparasitological evidence of hookworm and whipworm parasitism in the same population.

\section{Recommendations for future work}

Paleopharmacology, and archaeopalynology are in their infancy in Brazil. We are taking this opportunity to make suggestions to Brazilian archaeologists and ethnobotanists that would assist us with paleopharmacology.

We have no data regarding the amount of pollen contained in native plant medicines. We suggest that future work should include making medicinal preparations from the plants we found following traditional recipes. Then, pollen should be extracted and quantified using pollen concentration. This will provide baseline values to assess the potentiality that medicinal pollen would be ingested with traditional medicine.

A problem for us is distinguishing natural pollen rain from medicinally-ingested pollen. It would be useful to us if archaeologists submitted sediment samples from the coprolite-bearing strata. If this was done, then we could compare the pollen spectra from

Table 5

Summary of conclusions concerning the potential that the taxa really represent prehistoric medicinal use

\begin{tabular}{|c|c|c|c|c|c|c|}
\hline Taxon & $\begin{array}{l}\text { Of use to } \\
\text { ancient health }\end{array}$ & $\begin{array}{l}\text { Pollen to be expected } \\
\text { in preparation }\end{array}$ & $\begin{array}{l}\text { Medicine } \\
\text { ingested }\end{array}$ & Pollination & $\begin{array}{l}\text { Pollen abundant } \\
\text { in coprolite }\end{array}$ & $\begin{array}{l}\text { Summary of } \\
\text { evidence }\end{array}$ \\
\hline Alternanthera & Yes & Yes & Yes & Wind & Yes & Problematic \\
\hline Anacardium & Yes & Yes & Yes & Insect & Yes & Strong case \\
\hline Anadenanthera & Yes & No & Yes & Insect & No & Weak case \\
\hline Bauhinia & Yes & No & Yes & Insect & No & Weak case \\
\hline Borreria & Yes & Yes & Yes & Insect & Yes & Strong case \\
\hline Caesalpinia & Yes & Yes & Yes & Insect & No & Weak case \\
\hline Cecropia & Yes & Yes & Yes & Insect & No & Weak case \\
\hline Chenopodium & Yes & Yes & Yes & Wind & Yes & Problematic \\
\hline Croton & Yes & Yes & Yes & Insect & Yes & Problematic \\
\hline Mansoa & Yes & Yes & Yes & Insect & No & Weak case \\
\hline Sida & Yes & Yes & No & Insect & Yes & Problematic \\
\hline Terminalia & Yes & Yes & Yes & Insect & Yes & Strong case \\
\hline
\end{tabular}

A strong case can be made only for insect pollinated (entomophilous) taxa that have 'yes' entered in every space. "Problematic" is entered for any wind pollinated taxon or a taxon that has many non-medicinal species. 
the sediments to the coprolites. If taxa occur in both at the same frequencies, it is likely that they represent ambient, environmental signals. Also, knowing baseline frequencies of pollen would allow better recognition of anomalous amounts of pollen grains in coprolites.

We also recommend submitting many coprolites for pollen analysis. If many coprolites are studied (20 or more), the most common dietary and spice types can be quantified. Then looking for medicinal types will be easier. This is because recognizing variation in taxa and frequencies offers interpretive clues (Reinhard et al., 1991, 2002). For example, if a potential medicinal type occurs in all coprolites, it may be that this actually represents a food or spice. We also recommend applying pollen concentration, combined with analysis of pollen aggregates, to all coprolites in the future for refined interpretation, especially of anemophilous taxa (Reinhard, 1993).

We recommend that pollen concentration be consistently applied to all coprolites in the future.

Identifying the pollen of medicinal species, not genera, is a significant problem. Refined morphological analysis of pollen from the Sertão caatinga is an ongoing project to accomplish this goal. Finally, it is important to more thoroughly document the ethnobotany of medicinal plants in the Sertão. If we can identify the pollen of species within genera such as Croton and then match these to a comprehensive database of medicinal species of this genus, then inferring medicinal use would be less problematic.

\section{Acknowledgements}

We would like to thank the reviewers, Elizabeth Martinson Goodman and one anonymous individual for their suggestions and recommendations. We would also like to thank Owen Davis for organizing the Faeces Facies Symposium and for his editorial guidance in preparing this manuscript. This work was accomplished during 1993-1997, with a doctoral scholarship from the CNPq (Conselho Nacional de Desenvolvimento Científico e Tecnológico) and in 1998-2002 with funding from the FAPERJ (Fundação de Amparo à Pesquisa do Estado do Rio de Janeiro). Thanks to Fabio Parenti and Niéde Guidon, archaeologists responsible for the studied site. Special thanks to the leadership of BMS, NAMS and AASP for hosting the Faeces Facies Symposium, Joint Meeting of BMS, NAMS and AASP, September 11-13, 2002, at University College, London, England. Also thanks to the Fulbright Commission and the Council for International Exchange of Scholars who have provided funds for Reinhard's participation.

\section{References}

Araújo, A., Ferreira, L.F., Guidon, N., Maues da Serra Freire, N., Reinhard, K.J., Dittmar, K., 2000. Ten thousand years of head lice infection. Parasitol. Today 16, 269.

Bohrer, V.L., 1981. Methods of recognizing cultural activity from pollen in archaeological sites. Kiva 46, 135-142.

Bryant Jr., V.M., Holloway, R.G., 1983. The role of palynology in archaeology. In: Schiffer, M.B. (Ed.), Advances in Archaeological Method and Theory, vol. 6. Academic Press, New York, NY, pp. 191-219.

Chaves, S.A.M., 2000. New paleovegetational and paleoethnobotanical perspectives on Brazil's Central Plateau: a palynological proposal. Revista da Universidade de Guarulhos (Geociências V) número especial, dezembro, pp. 164-167.

Chaves, S.A.M., Reinhard, K.J., 2003. Paleopharmacology and pollen: theory, method and application. Mem. Inst. Oswaldo Cruz 98, 207-211.

Chaves, S.A.M., Renault-Miskovsky, J., 1996. Paléoethnologie, paléoenvironnement et paléoclimatologie au Piauí, Brésil: apport de l'étude pollinique de coprolithes humains recueillis dans le gisement préhistorique Pléistocène de "Pedra Furada". C. R. Acad. Sci. Paris, vol. t.322, pp. 1053-1060. série IIa.

Emperaire, L., 1983. La Caatinga du sud-est du Piauí (Brésil). Étude palethnologique. Paris. Ed. Recherche sur les civilisations. 135 pp.

Fry, G.F., 1977. Analysis of prehistoric coprolites from Utah. University of Utah Anthropological Papers, vol. 97. University of Utah Press, Salt Lake City, Utah.

Gamarra-Rojas, C., Santos, A.G., Mayo, S., Barbosa, M.R.V., Dalcin, E., Beale, C., 2002. Checklist das plantas do nordeste (Versão 11.2). Centro Nordestino de Informações sobre Plantas. Available at http://umbuzeiro.cnip.br/db/pnechk/. Viewed Sept. 30, 2004.

Gonçalves, M.L.C., Araújo, A., Ferreira, L.F., 2003. Human intestinal parasites in the past: new findings and a review. Mem. Inst. Oswaldo Cruz 98, 103-118.

Guidon, N., Parenti, F., da Luz, M., Guérin, C.L., Faure, M., 1994. Le plus ancien peuplement de l'Amérique: le Paléolithique du Nordeste brésilien. Bull. Soc. Préhist. Française 91, 246-250.

Hevly, R.H., 1981. Pollen production, transport and preservation: potentials and limitations in archaeological palynology. J. Ethnobiol. 1, 39-54.

Lessa, A., Guidón, N., 2002. Ostebbiographic analysis of skeleton I, Sitio Toca dos Coqueiros, Serra da capivara National Park, Brazil, 11,060 BP: first results. Am. J. Phys. Anthropol. 118, 99-110.

Martin, G., 1997. Pre-historia do nordeste do Brasil 2. ed. Universidade Federal do Pernambuco, Recife, Brazil. Ortiz, de Montellano B., 1975. Empirical Aztec medicine. Science 188, 215220.

Reinhard, K.J., 1993. The utility of pollen concentration in coprolite analysis: expanding upon Dean's comments. J. Ethnobiol. 9, 31-44.

Reinhard, K.J., 2000. Paleopharmacology. In: Ellis, L. (Ed.), Archaeological Method and Theory: An Encyclopedia. Garland Publishing, New York, pp. 432-447.

Reinhard, K.J., Bryant, V.M., 1992. Coprolite analysis: a biological perspective on archaeology. In: Schiffer, M.B. (Ed.), Advances in Archaeological Method and Theory, vol. 4. Univ. Arizona Press, Tucson, AZ, pp. 245-288.

Reinhard, K.J., McGuffie, M., Ambler, J.R., 1985. Diet and parasitism at Dust Devil Cave. Am. Antiq. 50, 819-824. 
Reinhard, K.J., Hamilton, D.L., Hevly, R.H., 1991. Use of pollen concentration in paleopharmacology: coprolite evidence of medicinal plants. J. Ethnobiol. 11, 117-134.

Reinhard, K.J., Araújo, A., Ferreira, L.F., Coimbra, C., 2001. American hookworm antiquity. Med. Anthropol. 20, 96-101.

Reinhard, K.J., Danielson, M., Daniels, D.R., Chaves, S., 2002. Multidisciplinary coprolite analysis. In: Geib, P.R., Keller, D.R. (Eds.), Bighorn Cave: Test Excavation of a Stratified Dry Shelter, Mojave County, Arizona. Bilby Research Center Occasional Papers 1. Northern Arizona University, Flagstaff, pp. $135-152$.
Riley, T.J., 1993. Ascarids, American Indians, and the Modern World: parasites and the Prehistoric record of a pharmacological tradition. Perspect. Biol. Med. 36, 369-375.

Shafer, H.J., Marek, M., Reinhard, K.J., 1989. Mimbres burial with associated colon remains from the NAN Ranch Ruin, New Mexico. J. Field Archaeol. 16, 17-30.

Sobolik, K.D., 1988. The importance of pollen concentration values from coprolites: an analysis of southwest Texas samples. Palynol. 12, 201-214.

Williams-Dean, G., 1978. Ethnobotany and cultural ecology of prehistoric man in southwest Texas. Ph.D. Dissertation, Texas A\&M University, College Station. 